\title{
Patient involvement and empowerment through the NPRD (Eastern Europe)
}

\author{
Dorica Dan \\ From 5th European Conference on Rare Diseases (ECRD 2010) \\ Krakow, Poland. 13-15 May 2010
}

Patient involvement and empowerment through the National Plans for Rare Disorders (NPRD) (Eastern Europe)

We present the current situation of the NPRD from Bulgaria, Romania and Hungary: three different countries confronted with the same problems and limits, and most probably not so different realities.

Bulgaria: the NPRD was officially launched on 1 January 2009. The draft for rare diseases and orphan drugs programme was prepared by BAPES and proposed to the Bulgarian Ministry of Health $(\mathrm{MoH})$ in November 2004. The national plan includes 9 priorities (total budget 11294515 Euro).

Romania: RPWA established RONARD - and organised the first working groups on a National Plan for RD on 9 August 2007. 1-2 November, RONARD organised the first National Conference on RD. 29 February 2008 - signed a partnership agreement with $\mathrm{MoH}-$ NPRD with 6 priorities. The first national programme on RD started in June 2008. Still there is no NPRD in the National Strategy for Health.

Hungary: there are several improvements but still before designing the Plan. HUFERDIS and enthusiastic professionals pushed it, but they have four running national health plans, and there is no more money for a new one.

In all three countries, Patient Organisations and medical professionals are the main engine for drafting and lobbying for a national strategy on RD. They organised information campaigns with stronger and stronger impact, help lines, contribute in designing social and medical health care services, initiate therapies, respite care, involve in research and clinical trials, etc. They

Correspondence: doricad@yahoo.com

Romanian National Alliance for Rare Diseases, Str. A. Iancu, no.29, Salaj County, 450143 Zalau, Romania organised working groups with members of the national alliances, networks and advocates at national level.

The Plan should be promoted both to parliament members and Ministry of Health. More "actors" have to be involved because RD patients need varied social assistance as much as medical care.

EURORDIS offered specific tools for lobby and advocacy actions toPOs. Recommendations and Communications of the EC give the best tool to promote RD as a public health and research priority.

Published: 19 October 2010

doi:10.1186/1750-1172-5-S1-032

Cite this article as: Dan: Patient involvement and empowerment through the NPRD (Eastern Europe). Orphanet Journal of Rare Diseases 2010 5(Suppl 1):032.
Submit your next manuscript to BioMed Central and take full advantage of:

- Convenient online submission

- Thorough peer review

- No space constraints or color figure charges

- Immediate publication on acceptance

- Inclusion in PubMed, CAS, Scopus and Google Scholar

- Research which is freely available for redistribution

Submit your manuscript at www.biomedcentral.com/submit
C Biomed Central 